\title{
Supply Chain Analysis in Public Works: The Role of Work Climate, Supervision and Organizational Learning
}

\author{
Noer SOETJIPTO ${ }^{1}$, Gogi KURNIAWAN ${ }^{2}$, Sulastri SULASTRI ${ }^{3}$, Ari RISWANTO ${ }^{4}$ \\ Received: September 10, 2020 Revised: November 02, 2020 Accepted: November 16, 2020
}

\begin{abstract}
The study aims to analyze the supply chain role of supervision, discipline, work climate, and organizational learning on the performance of community services at the public works. This study took a sample of employees through purposive sampling technique at the Public Works Office and Bina Marga in a regency in East Java. Data through questionnaire was collected through a 5-point Likert scale model. The results show that the application of employee discipline affects the performance of public services, with a contribution of $39.7 \%$, meaning that discipline and organizational learning are implementation factors that have an effect on public service performance. In stepwise regression analysis, the supervisory factor has a correlation with service performance, but it is less relevant, while the work climate is not relevant as a predictor variable to improve public service performance. The study revealed the importance of the supply chain policy of implementing good and clean governance and the enactment of the performance appraisal of the government apparatus established through Good Corporate Governance of the state apparatus. The findings provide a basis to encourage the public sector performance to smooth every step of supply chain management of every government project work, especially in the field of public services.
\end{abstract}

Keywords: Discipline, Supervision, Work Climate, Organizational Learning, Service Performance

JEL Classification Code: D20, D23, D73, D83

\section{Introduction}

In public service, service is like a supply chain activity that occurs as a process of direct interaction between someone who provides services and those who receive services, either directly or physically, or indirectly, namely, using communication means, but the goal is creating satisfaction in service recipients (Ratminto, 2005; Nguyen

${ }^{1}$ First Author and Corresponding Author. Lecturer, Sekolah Tinggi IImu Ekonomi (Institute of Economic Science) STIE YAPAN Surabaya, Indonesia [Postal Address: Gn. Anyar, Kec. Gn. Anyar, Surabaya City, East Java 60295, Indonesia]

Email: noersoetjipto.stieyapan@gmail.com

${ }^{2}$ Lecturer, Sekolah Tinggi IImu Ekonomi (Institute of Economic Science) STIE YAPAN Surabaya, Indonesia

${ }^{3}$ Lecturer, Sekolah Tinggi IImu Ekonomi (Institute of Economic Science) STIE YAPAN Surabaya, Indonesia

${ }^{4}$ Lecturer, Sekolah Tinggi Keguruan dan IImu Pendidikan (College of

Teacher Training and Education) STKIP PGRI Sukabumi, Indonesia

(C) Copyright: The Author(s)

This is an Open Access article distributed under the terms of the Creative Commons Attribution Non-Commercial License (https://creativecommons.org/licenses/by-nc/4.0/) which permits unrestricted non-commercial use, distribution, and reproduction in any medium, provided the original work is properly cited. et al., 2020). Grönroos (2007) provides an explanation that service is a form of activity or a series of invisible activities that occur due to interactions between service recipients and officers or other things provided by service providers intended to solve recipient problems service. In Indonesia, the Public Works Office at regional level is an extension of the central government under the Ministry of Public Works. As a government agency located in the regency, the Public Works Agency is the regional apparatus with the authority to delegate duties and responsibilities to carry out the process of regional autonomy, and good and clean governance in the field of public works tasks. Since it is a complicated task, in this regard, in the public sector management, leadership supervision is one of the supporting factors in achieving service performance. The development of attached supervision to the government internal control system places the leadership of the organization as the driving force and determinant of achieving organizational goals. The five elements in government's supply chain internal control system, including control environment, risk control, control activities, information and communication as well as monitoring, encourage organizational leadership to shift supervision from hard control to soft control (Mughal, 2019; 
Paais \& Pattiruhu, 2020). This statement is in line with the research by Brahmasari and Suprayetno (2008); Sami'an and N.W. (2013); Suseno and Munir (2013); and Mufti et al. (2019) stating that supervision and organizational learning have a positive effect on employee performance.

Another performance supporting factor is the discipline of employees who always comply with all applicable laws and regulations in the organization (Riswanto et al., 2019b; Riswanto et al., 2020). Civil servants' work discipline will be related to their daily work behavior in the organization starting from coming to work and doing work until leaving the office. The tendency to occur is delays in civil servants in completing their duties and responsibilities, as a result of a lack of discipline from each employee. Hidayat and Zainal (2012) stated that employee discipline has a positive effect on employee performance. This statement is in line with research by Widyastuti (2010), Amanah (2011), and Robiansyah (2013). Tantowi (2017) concluded that the work climate has an effect on performance. The public work service and its implementation are carried out by increasing discipline, supervision, creating a work climate, and encouraging every employee to carry out an organizational learning process as part of improving the quality of the institution in order to achieve good service performance. The study aims to analyze the role of supervision, discipline, work climate, and organizational learning on the performance of community services at the public works. To achieve the goals of quality governmental duties, this study examined the supply chain role of management of human resources in the Public Works office, in Ponorogo Regency, East Java, Indonesia. This was conducted by empirical testing to investigate the improvement the quality of service performance to the community through exploring the influential role of employee behavior, such as designing and determining types of services and terms that are considered more practical than before, making it easier for the community who need licensing services in a supply chain perspective.

\section{Literature Review}

\subsection{Supervision, Discipline, and Work Climate}

Sarwoto (2013) provides a definition of monitoring as management activities to ensure that each work can be carried out in accordance with the established plan and/or the desired results. Situmorang and Juhir (1998) explain that supervision is an action in every effort and action to determine the progress or achievement of the implementation of tasks based on the provisions and targets to be achieved. Supervision can also be a form of mindset and action pattern to provide understanding and awareness to someone or several people who are given tasks to be carried out using various available resources properly and correctly, so that there are no errors and deviations that can actually create losses by the institution or organization concerned.
Work discipline can be said to be an attitude of respecting, appreciating, and obeying various applicable rules, both written and unwritten, and being able to carry out rules and not commit violations in carrying out the duties and authority given to them (Sastrohadiwiryo, 2003). Veithzal and Jauvani (2014) showed discipline is an operational function of human resource management, which is classified as important, because the better employee discipline in the organization, the higher work performance can be achieved. According to Moekijat (2002), the main objective of applying discipline to employees is to maximize their work results by reducing the waste of time and energy. In addition, the application of behavior is to prevent damage or loss of company assets, as well as avoid accidents due to the carelessness of employees, while carrying out work tasks (Romi \& Ahman, 2020). The application of discipline aims to condition the behavior of respecting work time, and to resolve differences of opinion among employees and prevent disobedience that causes conflicts in the work environment.

Moreover, work climate is an adaptation of the concept of organizational climate. Work climate is the quality of the internal environment of an institution or company that is continuously experienced by employees, influencing their behavior, and that can be described in terms of a set of organizational characteristics (Tagiuri \& Litwin, 1968; Wirawan, 2007). Work climate is the employee's perception and is in constant contact with the company about what is or is happening in the company's internal environment on an ongoing basis, and affects work attitudes and behavior and employee performance, which then determines the performance of the institution (Riswanto et al., 2019a; Susilo et al., 2019; Hoa et al., 2020).

\subsection{Organizational Learning and Community Service in Public Works}

In terms of organizational learning, Garvin et al., (2008) explain that organizational learning is learning as a process of organizing employee creativity, increasing skills, training and transfer of knowledge, which are then expected to be able to improve behavior as the embodiment of new insights and knowledge applied in an organization. Organizational learning is an individual learning process in an organization that is carried out collectively and continuously to change the organizational culture and work climate of the organization to be better and more conducive (Schwandt \& Marquardt, 1999), and every employee is able to take advantage of maximum knowledge and skills to achieve organizational success (Soetjipto et al., 2020; Suryadi et al., 2019). Organizational learning is a process of developing employee skills that is carried out continuously by organizations to create a better future (Senge, 2006; Garvin et al., 2008; ). The organizational learning implemented in the government office has been mostly in the form of training and human resource 
development as well as information and communication technology tools related to sustainable performance and as a tool for making decisions and taking appropriate actions (Senge, 2006; Basten \& Haamann, 2018).

In term of community service, Moenir (2006) explains that service is a form of activity to provide something that is accompanying, fulfilling, and providing a service in the form of an action or an item to provide satisfaction even though the result is not always a physical product. Pasolong (2013) provides a definition of service, which is basically a form of activity of a person or group or an organization that is carried out directly or indirectly to meet the needs of other parties or people who need services. Herawati et al. (2016) explain service as a form of activity or act of providing services from one party to another, in the form of good, friendly and pleasant behavior and attitudes and high ethics so as to foster good, satisfying and appreciative reactions from the party receiving the service. Based on the description, the hypotheses proposed in this study are:

H1: Supervision, discipline, work climate and organizational learning have simultaneous effects on the performance of community services at the public works.

H2: Discipline and organizational learning represent other factors that have an influence on the performance of community services at the public works.

\section{Research Methods}

This research uses descriptive quantitative method, through an ex-post facto approach, which examines observable social phenomena, then takes measurements, each of which is described in several components of the problem, variables and indicators. The process of measurement is an essential part of quantitative research, because it provides a fundamental relationship between empirical observation and the mathematical expression of quantitative relationships (Ghozali, 2011). Taking into account the number of members of the population, the sampling in this study used the total population study, which is to take all members of the population as research subjects (Suryabrata, 1998). Based on the consideration of the number of employees, in this quantitative study the number of samples taken was 42 employees at the Public Works and Bina Marga of Ponorogo Regency. Data were collected through closed and open questionnaires. The open questionnaire contains the identity of the research subject, and the closed questionnaire is arranged in a Likert scale model with a statement given a choice of five answers. Validity can be interpreted as the accuracy of a measurement instrument in performing its size function, therefore every measuring instrument used as a measurement scale must be tested for validity (Azwar, 1997).
Table 1: Validity Testing

\begin{tabular}{|l|l|c|}
\hline No. & \multicolumn{1}{|c|}{ Supervision } & Rxy value \\
\hline $\mathbf{1}$ & Steering controls & 0.555 \\
\hline $\mathbf{2}$ & Concurrent controls & 0.816 \\
\hline $\mathbf{3}$ & Feedback controls & 0.602 \\
\hline No. & \multicolumn{1}{|c|}{ Discipline } & Rxy value \\
\hline $\mathbf{1}$ & Procrastination & 0.663 \\
\hline $\mathbf{2}$ & $\begin{array}{l}\text { Violation of attendance } \\
\text { procedures }\end{array}$ & 0.595 \\
\hline $\mathbf{3}$ & Negligent task completion & 0.522 \\
\hline $\mathbf{4}$ & Careless behavior & 0.550 \\
\hline $\mathbf{5}$ & The occurrence of criminal acts & 0.515 \\
\hline $\mathbf{6}$ & Conflicting employment relations & 0.658 \\
\hline No. & \multicolumn{1}{|c|}{ Work climate } & $\mathbf{R x y ~ v a l u e ~}$ \\
\hline $\mathbf{1}$ & Leader behavior & 0.660 \\
\hline $\mathbf{2}$ & Flow of communication & 0.593 \\
\hline $\mathbf{3}$ & Practice decision making & 0.370 \\
\hline $\mathbf{4}$ & Interaction influencing process & 0.264 \\
\hline $\mathbf{5}$ & Goal setting and control & 0.730 \\
\hline No. & Organizational learning & $\mathbf{R x y ~ v a l u e ~}$ \\
\hline $\mathbf{1}$ & Personal Mastery & 0.461 \\
\hline $\mathbf{2}$ & Vision Sharing & 0.715 \\
\hline $\mathbf{3}$ & Mentality & 0.744 \\
\hline $\mathbf{4}$ & Team Learning & 0.597 \\
\hline $\mathbf{5}$ & Systemic Thinking & \\
\hline & & \\
\hline
\end{tabular}

Table 2: Validity testing of the service performance scale

\begin{tabular}{|l|l|c|}
\hline No. & \multicolumn{1}{|c|}{ Service Performance } & Rxy value \\
\hline $\mathbf{1}$ & Openness & 0.742 \\
\hline $\mathbf{2}$ & Convenience & 0.812 \\
\hline $\mathbf{3}$ & Certainty & 0.761 \\
\hline $\mathbf{4}$ & Justice & 0.777 \\
\hline $\mathbf{5}$ & Professionalism & 0.852 \\
\hline $\mathbf{6}$ & Facilities & 0.626 \\
\hline $\mathbf{7}$ & Security & 0.659 \\
\hline $\mathbf{8}$ & Complaints Handling & 0.663 \\
\hline
\end{tabular}

Table 3: Research Scale Reliability Test

\begin{tabular}{|l|l|c|}
\hline No. & \multicolumn{1}{|c|}{ Scale } & $\boldsymbol{\alpha}$ Value \\
\hline $\mathbf{1}$ & Supervision & 0.835 \\
\hline $\mathbf{2}$ & Discipline & 0.796 \\
\hline $\mathbf{3}$ & Work climate & 0.731 \\
\hline $\mathbf{4}$ & Organizational learning & 0.855 \\
\hline $\mathbf{5}$ & Service Performance & 0.921 \\
\hline
\end{tabular}


According to Azwar (1997), item validity can be tested by comparing the total item correlation coefficient that is greater than the value of 0.250 . This value is used to determine the validity coefficient of each item as well as to measure the level of difference power. Based on the results of the analysis of the validity test on the research scale, it can be said that all items used in this study are valid.

The measuring instrument can be declared reliable if the measurement results and values are consistent as the initial measurement. The reliability test of the two research questionnaires was done by using Cronbach's alpha.

\section{Results}

\subsection{Descriptive Statistics}

In this study, the data analysis technique was performed using stepwise regression analysis. Stepwise regression is one method to get the best model from a regression analysis. By definition, it is a combination of forward and backward methods; the first variable that is entered is the variable with the highest and significant correlation with the dependent variable, the second entry variable is the variable with the highest partial correlation and is still significant; after certain

Table 4: Descriptive Statistics

\begin{tabular}{|l|c|c|c|}
\hline Variable & Mean & $\begin{array}{c}\text { Std. } \\
\text { Deviation }\end{array}$ & N \\
\hline Service Performance & 2.8810 & .73923 & 42 \\
\hline Discipline & 2.9762 & .51741 & 42 \\
\hline Supervision & 2.9524 & .62283 & 42 \\
\hline Working Climate & 2.5714 & .59028 & 42 \\
\hline Organizational learning & 2.8333 & .58086 & 42 \\
\hline
\end{tabular}

variables are entered into the model then other variables are evaluated if there is a variable that is not significant, then the variable is excluded.

\subsection{Scale Reliability}

The results of the mean test show that the mean value of each independent variable shows that the discipline and supervision variables have the highest mean value, then organizational learning. Furthermore, the correlation testing stage for estimating the independent variables related to service performance variables is in Table 5 .

The results of the Pearson correlation analysis show that discipline has a coefficient of 0.630 with $\mathrm{p}=0.000<0.05$ ), which means that discipline has a correlation with service performance. In the control factor, the correlation coefficient value is obtained at 0.517 with $\mathrm{p}=0.000<0.05$ ), which means that the control factor has a correlation with service performance. The work climate factor obtained a coefficient value of 0.216 with $\mathrm{p}=0.085>0.05$ ), which means that the work climate has no correlation with service performance, while organizational learning has a coefficient value of 0.577 with $\mathrm{p}=0.000<0.05$ ), which means that organizational learning has a correlation with service performance.

Table 5: Scale Reliability Test

\begin{tabular}{|l|c|c|}
\hline \multirow{2}{*}{ Variable } & \multicolumn{2}{|c|}{ Service Performance } \\
\cline { 2 - 3 } & rxy & sig. \\
\hline Discipline & 0.630 & 0.000 \\
\hline Supervision & 0.517 & 0.000 \\
\hline Working Climate & 0.216 & 0.085 \\
\hline Organizational learning & 0.577 & 0.000 \\
\hline
\end{tabular}

Table 6: Stepwise regression test

\begin{tabular}{|c|c|c|c|c|c|c|c|c|c|}
\hline \multirow[b]{2}{*}{ Model } & \multirow[b]{2}{*}{$\mathbf{R}$} & \multirow{2}{*}{$\begin{array}{c}\mathbf{R} \\
\text { Square }\end{array}$} & \multirow{2}{*}{$\begin{array}{l}\text { Adjusted R } \\
\text { Square }\end{array}$} & \multirow{2}{*}{$\begin{array}{l}\text { Std. Error of the } \\
\text { Estimate }\end{array}$} & \multicolumn{5}{|c|}{ Change Statistics } \\
\hline & & & & & $\begin{array}{c}R \text { Square } \\
\text { Change }\end{array}$ & F Change & $d f 1$ & $d f 2$ & $\begin{array}{l}\text { Sig. } F \\
\text { Change }\end{array}$ \\
\hline 1 & $.630^{\mathrm{a}}$ & .397 & .382 & .58116 & .397 & 26.337 & 1 & 40 & .000 \\
\hline 2 & $.747^{b}$ & .558 & .535 & .50383 & 161 & 14.220 & 1 & 39 & .001 \\
\hline
\end{tabular}

a. Predictors: (Constant), Discipline; b. Predictors: (Constant), Discipline, organizational learning 
Table 7: Excluded Variables

\begin{tabular}{|c|c|c|c|c|c|c|}
\hline \multirow{2}{*}{\multicolumn{2}{|c|}{ Model }} & \multirow{3}{*}{$\begin{array}{l}\text { Beta } \\
.293^{\mathrm{a}}\end{array}$} & \multirow{3}{*}{$\begin{array}{c}\mathbf{t} \\
2.231\end{array}$} & \multirow{3}{*}{$\begin{array}{l}\text { Sig. } \\
.031\end{array}$} & \multirow{3}{*}{$\begin{array}{c}\begin{array}{c}\text { Partial } \\
\text { Correlation }\end{array} \\
.336\end{array}$} & \multirow{3}{*}{$\begin{array}{c}\text { Collinearity Statistics } \\
\text { Tolerance } \\
.797\end{array}$} \\
\hline & & & & & & \\
\hline \multirow[t]{3}{*}{1} & Supervision & & & & & \\
\hline & Working Climate & $.139^{\mathrm{a}}$ & 1.125 & .268 & .177 & .984 \\
\hline & Organizational learning & $.422^{\mathrm{a}}$ & 3.771 & .001 & .517 & .903 \\
\hline \multirow[t]{2}{*}{2} & Supervision & $.116^{\mathrm{b}}$ & .868 & .391 & .139 & .640 \\
\hline & Working Climate & $.096^{\mathrm{b}}$ & .883 & .383 & .142 & .972 \\
\hline
\end{tabular}

a. Predictors in the Model: (Constant), Discipline b. Predictors in the Model: (Constant), Discipline, organizational learning c. Dependent Variable: Service Performance

\subsection{Stepwise Regression Analysis}

Table 6 model 1 shows a correlation coefficient of 0.630 , which explains the discipline variable has a strong correlation to service performance; the coefficient of determination shows that employee discipline is able to contribute to service performance by $39.7 \%$, while the $p$-value is $0.000<0.05$, which means that discipline has an effect on performance. Model 2 shows the value of the correlation coefficient between discipline and organizational learning of 0.747 , which means the relationship between discipline and organizational learning with service performance is strong. The coefficient of determination shows that discipline and organizational learning are able to contribute effectively to service performance by $55.8 \%$ while the $p$-value is $0.001<0.05$, which indicates that discipline and organizational learning simultaneously affect service performance.

The standard error value of estimate shows that the discipline and organizational learning are more accurate to be used as a factor to predict service performance than discipline as a single variable.

In Table 6, it is known in model 1 that the control variable obtains the value of $\mathrm{t}=2.231, \mathrm{r}=0.336$, and $\mathrm{p}=0.031<0.05$, which means that supervision has an influence on service performance, with a relatively weak coefficient level or $33.6 \%$. Meanwhile, organizational learning obtained a value of $\mathrm{t}=3.371, \mathrm{r}=0.517$, with $\mathrm{p}=0.001<0.05$, which means that organizational learning affects service performance. However, the work climate variable obtained the value of $\mathrm{t}=1.125, \mathrm{r}=0.117$, with $p=0.268>0.05$, which indicates that the work climate has no effect on service performance.

Testing model 2 shows the control variable obtains a value of $\mathrm{t}=0.867, \mathrm{r}=0.139$, with $\mathrm{p}=0.391>0.05$, which indicates that supervision has no effect on service performance. Likewise, the work climate variable obtained a value of $\mathrm{t}=0.883$, $\mathrm{r}=0.142$, with $\mathrm{p}=0.383>0.05$, which means that the work climate has no effect on service performance.

The first thing needed to create an organizational learning is discipline, which is not based on a supervisory hierarchy, but instead refers to standard and operational work procedures (Senge, 2006). Second, employees are aware that the community also has inherent power to find solutions to problems when faced with the reality of the old model bureaucracy system, which is considered too complicated and impractical, so that the community, especially business actors, assesses the performance of the Ponorogo's Public Works as still far or not good. According to Patmarina and Erisna (2012), learning in an organization means every employee's behavior collectively has been directed to discipline. Organizational learning is close to application or followed by discipline as a learner. Moekijat (1991) explained that in work discipline every employee is required to have the ability to absorb the established rules, norms, laws and regulations, so that every employee can consciously implement and obey them. Employee discipline according to Herawati et al., (2016); Safitri et al., (2018) is an organizational learning process, in which discipline is a major factor, namely, the awareness of employees to the rules or regulations imposed in the company. Work discipline is very important in an effort to ensure the maintenance of order and the smooth running of the organization's operations. Gephart (2006) explains that discipline and organizational learning is a culture that is inherent and binding an organization together. A culture of organizational learning is based on openness and trust, where employees are supported and rewarded for learning and innovating, and one which promotes experimentation, takes risks, and rewards the welfare of all employees in order to achieve or perform in their respective fields of work. 


\section{Conclusion}

The results show that, in supply chain analysis, service performance in the Public Works and Bina Marga Offices in Ponorogo, East Java, Indonesia, can be achieved through discipline, work behavior and organizational learnings. The results in a supply chain perspective showed that these two things go hand in hand, that in the learning process, every employee is required to be able to behave in a disciplined manner, and discipline is part of the learning process. It can be said that discipline and organizational learning are two aspects that are interconnected to produce a satisfactory service performance, especially in supply chain licensing in public works. Discipline has a good influence on the formation of service performance in the Public Works Office, and the application of disciplined behavior in completing work tasks has a good impact on improving service performance. Another consideration in supply chain is related to the supervisory factor. It is classified as being able to support the achievement of service performance. However, the findings demonstrate that supervisory factor is less relevant when applied in Ponorogo's Public Works Office, because discipline and organizational learning are able to represent aspects of supervision. This means that employees who are disciplined and able to learn about institutional advancement are not so dependent on supervision to carry out orderly work.

\section{References}

Amanah, D. (2011). Introduction to Management. Medan, Indonesia: Unimed.

Azwar, S. (1997). Reliability and validity. Yogyakarta, Indonesia: Pustaka Pelajar.

Basten, D., \& Haamann, T. (2018). Approaches for organizational learning: A literature review. SAGE Open, 8(3), 2158244018794224 .

Brahmasari, I. A., \& Suprayetno, A. (2008). The influence of work motivation, leadership and organizational culture on employee job satisfaction and its impact on company performance (Case study at PT. Pei Hai International Wiratama Indonesia). Jurnal Manajemen dan kewirausahaan, 10(2), 124-135.

Garvin, D. A., Edmondson, A. C., \& Gino, F. (2008). Is yours a learning organization? Harvard Business Review, 86(3), 109.

Gephart Jr, R. P. (2006). Ethnostatistics and organizational research methodologies: An introduction. Organizational Research Methods, 9(4), 417-431.

Ghozali, I. (2011). Multivariate Analysis Applications With IBM and SPSS Programs. Semarang: BP Universitas Diponegoro.

Grönroos, C. (2007). Service management and marketing: customer management in service competition. Hoboken: John Wiley \& Sons.

Herawati, N. L. M., Suputra, I. D., \& Budiasih, I. G. A. N. (2016). The Effect of Supervision of Leaders, Discipline and Employee
Competence on Employee Performance of the Inspectorate of Tabanan Regency. E-Jurnal Ekonomi Dan Bisnis Universitas Udayana, 5(7).

Hidayat, Z., \& Taufiq, M. (2012). The Influence of Work Environment and Work Discipline and Work Motivation on Employee Performance of Local Water Company (PDAM) Lumajang Regency. Wiga: Jurnal Penelitian Ilmu Ekonomi, 2(1), 36644.

Hoa, N. D., Ngan, P. T. H., Quang, N. M., Thanh, V. B., \& Quyen, H. V. T. (2020). An Empirical Study of Perceived Organizational Support and Affective Commitment in the Logistics Industry. Journal of Asian Finance, Economics and Business, 7(8), 589598. https://doi.org/10.13106/jafeb.2020.vol7.no8.589

Moekijat, D. (1991). Training and Human Resource Development. Bandung, Indonesia: Mandar Maju.

Moenir, H. A. S. (2006). Public Service Management in Indonesia. Jakarta, Indonesia: Bumi Aksara.

Mufti, M. Y., Pudjiarti, E. S., \& Darmanto, S. (2019). Analysis of second order person-environment fit on innovative work behavior and individual performance. Arthatama Journal of Business Management and Accounting, 3(2), 21-39.

Mughal, M. R. (2019). Impact of Green Supply Chain management practices on performance of manufacturing companies in Jordan: a moderating role of supply chain traceability. Arthatama Journal of Business Management and Accounting, 3(2), 1-20.

Nguyen, D. T., Pham, V. T., Tran, D. M., \& Pham, D. B. T. (2020). Impact of Service Quality, Customer Satisfaction and Switching Costs on Customer Loyalty. Journal of Asian Finance, Economics and Business, 7(8), 395-405. https://doi. org/10.13106/jafeb.2020.vol7.no8.395

Paais, M., \& Pattiruhu, J. R. (2020). Effect of motivation, leadership, and organizational culture on satisfaction and employee performance. Journal of Asian Finance, Economics and Business, 7(8), 577-588. https://doi.org/10.13106/jafeb.2020. vol7.no8.577

Pasolong, H. (2013). Public Administration Theory. Bandung, Indonesia: Alfabeta.

Patmarina, H., \& Erisna, N. (2012). The Effect of Work Discipline on Employee Performance Mediated by the Productivity of CV. Laut Selatan Jaya in Bandar Lampung. Jurnal manajemen dan Bisnis, 3(1).

Ratminto, A. S. W. (2005). Service management. Yogyakarta, Indonesia: Pustaka Pelajar.

Riswanto, A., Hurriyati, R., Wibowo, L. A., \& Gaffar, V. (2019a). Effect of Market Orientation on Business Performance in MSMEs as Mediating by Dinamic Marketing Capabilities. Calitatea, 20(172), 78-83.

Riswanto, A., Hurriyati, R., Wibowo, L. A., \& Gaffar, V. (2019b). Empirical Assessment of the Role of Product Innovation in Dynamic Marketing Capabilities and Company Performance. Quality-Access to Success, 20(173). 
Riswanto, A., Rasto, R., Hendrayati, H., Saparudin, M., Abidin, A., \& Eka, A. (2020). The role of innovativeness-based market orientation on marketing performance of small and mediumsized enterprises in a developing country. Management Science Letters, 10(9), 1947-1952.

Robiansyah, R. (2013). Systems and Procedures of Intern Control on PT. Panama at Sangatta. Ekonomia, 2(1), 290-296.

Romi, M. V., \& Ahman, E. (2020). Islamic Work Ethics-Based Organizational Citizenship Behavior to Improve the Job Satisfaction and Organizational Commitment of Higher Education Lecturers in Indonesia. International Journal of Higher Education, 9(2), 78-84.

Safitri, C. L., Setyanti, S. W. L. H., \& Sudarsih, S. (2018). Knowledge Sharing as a Mediation of the Influence of Learning Organization on Employee Performance. Jurnal Inspirasi Bisnis dan Manajemen, 2(1), 79-90.

Sami'an, S., \& Estu Aprilian N.W. (2013). The Influence of Leadership and Supervision on Employee Performance of PT. Kereta Api Indonesia (Persero) at the Semarang Daop IV Office. Jurnal EMBA, 23(1), 10-14.

Sarwoto, S. (2013). Al-Ghazali's View of Moral Education. Al-Mabsut: Jurnal Studi Islam dan Sosial, 6(1), 46-67.

Sastrohadiwiryo, B. S. (2003). Management of Indonesian Workers Administrative and Operational Approaches. Jakarta, Indonesia: Bumi Aksara.

Schwandt, D., \& Marquardt, M. J. (1999). Organizational learning. Boca Raton, FL: CRC Press.

Senge, P. M. (2006). The fifth discipline: The art and practice of the learning organization. Currency.

Situmorang, V. M., \& Juhir, J. (1998). Legal Aspects of Inherent Supervision [Indonesian]. Jakarta, Indonesia: Rineka Cipta.

Soetjipto, N., Susilo, D. E., \& Riswanto, A. (2020). Supply Chain Strategies in Mediating the Effect of Knowledge Management on Business Performance. Humanities \& Social Sciences Reviews, 8(1), 448-455.
Suryabrata, S. (1998). Research methodology [Indonesian]. Jakarta, Indonesia: RajaGrafindo Persada.

Suryadi, A., Hufad, A., Komar, O., \& Riswanto, A. (2019). Entrepreneurial Skills at Retirement Age: Analysis of the Importance of Training for Retiring Employees in Bandung City. International Journal of Entrepreneurship, 23(2).

Suseno, V. S., \& Munir, M. (2013). The Influence of the Work Environment on the Work Productivity of Employees in the Production Section in the Sanggan Sector (Case Study at PT. Gudang Garam Tbk.). Jurnal Cendekia, 11(2), 58-67.

Susilo, D. E., Soetjipto, N., Triwulan, A., Djuwitawati, Ratnaningtyas, Riswanto, A., Wasis, W., \& Jaya, F. P. (2019). The Effect of Employee Commitment, Culture, and Leadership Style On Good Governance Performance of Jombang District Government. Revista ESPACIOS, 40(27).

Tagiuri, R., \& Litwin, G. H. (Eds.). (1968). Organizational Climate: Exploration of a Concept. Boston: Division of Research, Graduate School of Business Administration, Harvard University Law School.

Tantowi, R. (2017). Pengaruh Iklim Organisasi Terhadap Kinerja Karyawan Pada PT. Bank Danamon Simpan Pinjam Unit Metro. Jurnal Bisnis Darmajaya, 2(2), 134-145.

Taylor, G. S., Templeton, G. F., \& Baker, L. T. (2010). Factors influencing the success of organizational learning implementation: A policy facet perspective. International Journal of Management Reviews, 12(4), 353-364.

Veithzal, R., \& Jauvani, S. E. (2014). Human Resource Management for Companies. Jakarta, Indonesia: Raja Grafindo Persada.

Widyastuti, Y. (2010). The influence of perceptions of employee remuneration, work motivation and work discipline on employee performance in the service office of the State Treasury (Kppn) pilot attack Banten province. Jurnal Administrasi Publik, 1(2).

Wirawan, N. (2007). Organizational Culture and Climate. Jakarta, Indonesia: Salemba Empat. 